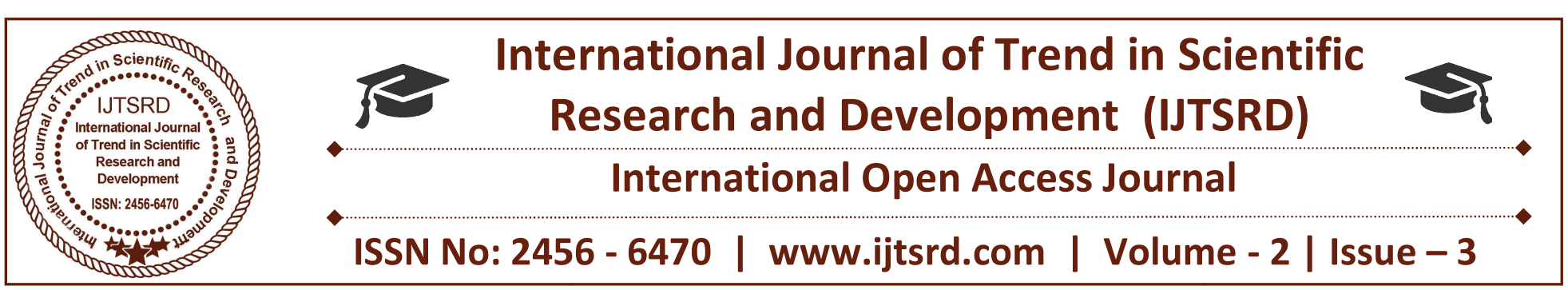

\title{
Study on Risk And Return Factors of Selected Banks in Bombay Stock Exchange (BSE)
}

\author{
Ebrahim Al-gamal \\ Research Scholar, Commerce Department, Mangalore \\ University, Mangalore, Karnataka, India
}

\author{
Dr. Abbokar Siddiq \\ Department of Studies in Commerce, University \\ College, Mangalore University, Mangalore, \\ Karnataka, India
}

\section{ABSTRACT}

Banks extreme importance of the economic stability of the country, as well as great importance when it is working on a compilation of the savings of individuals and re-invest in exchange for the return, as well as the provision of funds to finance economic projects, which leads to an increase in the gross national product of the country. As the purpose of the study is to understand the bank's stock movement in the Indian capital market through the risk and return factors, which has direct or indirect impact, The objective of the study is to identify the risk and return factors of Indian capital market with regard to select banking sector, to examine the efficiency of CAPM and other risk factors in the Bombay stock exchange (BSE). Along with scope of the limited of the operation of the Bombay stock exchange (BSE). This study is based on the risk-return tool and CAPM to analyze the bank's stock. we found this model to be suitable because it measures the profitability of the selected banks. The result of the study showed that the private banks making better than the public banks in the market and observed that the bank sector is an effective sector in the Indian capital market. The study recommended for public sector banks to attract more investors, it has to make some advantages to present investors and it should make wise decisions while making investments and provide more benefits to the investor.

Keywords: Risk and Return Factors, Banks, Bombay stock exchange

\section{INTRODUCTION}

Risk refers to the possibility of loss, even it is known as the negative different between actual outcome and expected outcome of the investment. The wider range of possible outcomes the greater the risk. Return is the positive different between actual outcome and expected outcome of the investment. It represents the yield of the investment. There is a positive relationship between the risks and return, for high return investor has to take some risk, so the investor has to trade off between risk and return in his investment.

Banks are the important source of finance for most business and it plays an important role in the economic development of every nation. Banks in India started during 18 th century. RBI control and regulates banking system in India. In India there is existence of public and private sector banks, which plays an important role in the development of country. After the entry of private sector banks during 1991, public sector banks increased their speed to compete with private banks. Finance is regarded as lifeblood and acts as backbone for every bank. Indian banking system is a mixed one, which mainly comprises of these three types of banks i.e., public sector banks, private sector banks and foreign banks. It is a significant part of the financial sector of the country. Every bank is trying to provide better services to their customers to ensure maximum satisfaction, as it is a service-based sector. Evaluation of performance of banks leads to improved activities and functions of banks. Analyzing performance of banks in an 
economy is very important due to the key role-played by financial sectors.

Banking industry is one sector of the capital market, it is consider as the backbone of the country's economy, has always played a positive key role in prevention the economic disaster from reaching horrible volume in the country.

The Indian capital market plays a very important role in promoting economic growth through the mobilization of long-term savings and the savings get invested in the economy for productive purpose. Capital market in India has grown in the last ten years. The governments, through Reserve Bank of India, as well as financial institutes also raise a lot of money from these markets.

\section{LITERATURE REVIEW}

Chhaochhria. S, (2008) conduct study on "Capital Market Development " represents the India has a more modern financial and banking system than China that allocates capital in a more efficient manner. However, the study is skeptical about who would emerge with the stronger capital market, as both the country is facing challenges regarding their capital markets.

JuhiAhuja(2012)discussed about the Indian Capital Market, has presents a review of Indian Capital Market\& its structure. in last decade or so, it has been observed that there has been a paradigm shift in India capital market. The application of many reforms\& developments in Indian capital market has made the Indian capital market comparable with the international capital markets. Now, the market features a developed regulatory mechanism and a modern market infrastructure with growing market capitalization, market liquidity, and mobilization of resources. The emergence of Private Corporate Debt market is also a good innovation replacing the banking mode of corporate finance. However, the market has witnessed its worst time market and the recent global with the recent global financial crisis that originated from the US sub-prime mortgage market and spread over the entire world as a contagion . The capital market of India delivered a sluggish performance.

Setiawan et.al, (2013) have taken an empirically examination of the performance of Syariah stocks with conventional stocks listed on Indonesia Stock Exchange using Risk-Adjusted Return measurements.
They found that there is no significant difference on risk and returns, measured by weekly return, standard deviation and beta, between both Syariah and conventional stocks. Furthermore, they also evaluated the performance of both Syariah and conventional stocks portfolio by employing Risk-Adjusted Return measurement, consisting of Sharpe ratio, Treynor ratio and Jensen's Alpha. They tried to compare the stock returns with financial results and found that Return on Equity was most influential variable in the research.

Ansar et.al, (2014) developed "A-Y Model" to measure the performance of a return and risk of the portfolio and analyze it during the bull and the bear market. The results of the model indicates that there is no consistent performance exist between the portfolio return and target risk.

Ibbotson\& Kim (2015) studied about" Risk and Return Within Stock Market " This paper studies return-predictive characteristics of U.S. securities, including beta, volatility, size, value, liquidity, and momentum. Value and low liquidity have the largest impact on returns, while low beta, low volatility, and low liquidity have the best performance when measured on a risk-adjusted basis. Contrary to the conventional wisdom on risk and reward, most portfolio sorting metrics exhibit an inverse risk-return relationship, with lower risk portfolios outperforming higher risk portfolios. A broad theme that emerges from the empirical evidence is that popularity underperforms.

\section{OBJECTIVES OF THE STUDY}

The main purpose of this study is to identify the risk and return factors of Indian capital market with regard to select banking sector and to examine the efficiency of CAPM and other risk factors in the Bombay stock exchange (BSE).

\section{RESEARCH METHOD}

\section{Research design}

The present empirical research methodology has used risk-return test with related to CAPM; empirical research methods are a class of research methods in which empirical observation or data collected in order to achieve particular research objectives . The study is conducted on selected securities listed in BSE and are analyzed whether the securities have provided sufficient returns for the risk involved with it is 
security is overloaded or undervalued in the market. The performance evolution of securities has been carried out for the period of six years from 2010 to 2015 .

The annual return (in percentage terms ) of the stock and the index is calculated by the formula of:

Arithmetic mean $(\mathrm{AM})=\mathrm{ERi} / \mathrm{n}$

,data has been analyzed from January 2010 to 31 December 2015 (for period of 6 years). Even stock splits are considered over a period of time.

The beta value of the stock is calculated using the formula. Beta is the only measure in the CAPM concept. Expected return calculation needs the risk free rate . RF is Treasury bill. So we have assumed it as $8 \%$ in the formula:

\section{Data Analysis:}

\section{Calculation of Return Market Sensex:}

\begin{tabular}{|l|l|l|l|}
\hline Year & Open & Close & returns \\
\hline $\mathbf{2 0 1 0}$ & 17473.45 tiona & 20509.09 all & 0.174 \\
\hline $\mathbf{2 0 1 1}$ & 20621.61 ind in & 15454.92 & -0.25 \\
\hline $\mathbf{2 0 1 2}$ & 15534.67 & 19426.71 & 0.25 \\
\hline $\mathbf{2 0 1 3}$ & 19513.45 & 21170.68 & 0.085 \\
\hline $\mathbf{2 0 1 4}$ & 21222.19 & 27499.42 & 0.3 \\
\hline $\mathbf{2 0 1 5}$ & $27485.77: 24.56$ & 26117.54 & -0.05 \\
\hline & Average Return & & 0.085 \\
\hline
\end{tabular}

\section{Table1: return of market (sensex)}

Geometric mean $\{(1+\mathrm{R} 1) *(1+\mathrm{R} 2) *$ $\left..(1+\mathrm{R} 6)^{\wedge}(1 / 6)-1\right\}$

Therefore expected return on market is $=0.06689$ or $\% 6.7$

\section{Calculation of Market Variance:}

\begin{tabular}{|l|l|l|l|}
\hline & $\mathbf{X}$ & $\boldsymbol{x}-\mathbf{X}$ & $(\boldsymbol{x}-\mathbf{X}) 2$ \\
\hline & 0.174 & 0.089 & 0.007921 \\
\hline & -0.25 & -0.335 & 0.1156 \\
\hline & 0.25 & 0.165 & 0.027225 \\
\hline & 0.085 & 0 & 0 \\
\hline & 0.3 & 0.215 & 0.0462 \\
\hline & -0.05 & -0.135 & 0.0196 \\
\hline Average & 0.085 & Sum & 0.216546 \\
\hline & & Co-Variance & 0.03616 \\
\hline
\end{tabular}

Table2: market Variance 
From the above calculation we come to know about the average rate of return of the market is 0.085 and the expected market return (which we calculate by Geometric mean formula) of SENSEX is \%6.7, and the market variance of the SENSEX is 0.03616 .

Calculation return and risk of the banks:

\begin{tabular}{|l|l|l|l|l|l|l|}
\hline BANKS & $\begin{array}{l}\text { Average } \\
\text { RETURNS }\end{array}$ & $\begin{array}{l}\text { Geometric } \\
\text { mean }\end{array}$ & $\begin{array}{l}\text { CO- } \\
\text { VARIANCE }\end{array}$ & BETA & CAPM & REMARKS \\
\hline STATE BANK & $-0.54 \%$ & $8.21 \%$ & $7.381 \%$ & 2.041 & $5.32 \%$ & OVER PRICED \\
\hline CANARA BANK & $-8.458 \%$ & $4.22 \%$ & $7.651 \%$ & 2.12 & $5.22 \%$ & OVER PRICED \\
\hline $\begin{array}{l}\text { BANK OF } \\
\text { BARODA }\end{array}$ & $7.4 \%$ & $15.8 \%$ & $6.437 \%$ & 1.78 & $5.666 \%$ & UNDER PRICED \\
\hline $\begin{array}{l}\text { ICICI } \\
\text { BANK }\end{array}$ & $5.58 \%$ & $13.45 \%$ & $7.086 \%$ & 1.96 & $5.43 \%$ & UNDER PRICED \\
\hline HDFC BANK & $20.755 \%$ & $23.28 \%$ & $3.6 \%$ & 0.99 & $6.70 \%$ & UNDER PRICED \\
\hline YES BANK & $17.528 \%$ & $28 \%$ & $8.14 \%$ & 2.25 & $5,05 \%$ & UNDER PRICED \\
\hline
\end{tabular}

Table3: CABM of banks.

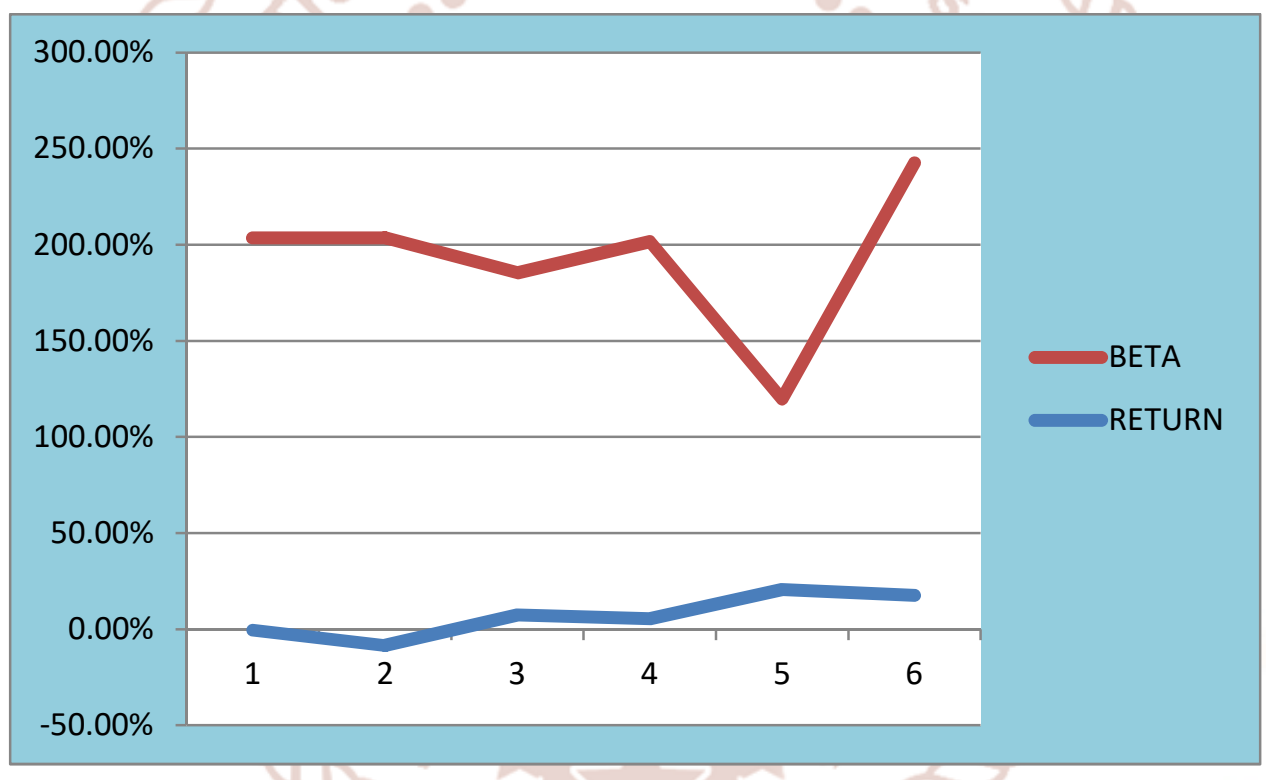

Figure 1: Beta and Return.

\section{CONCLUSION}

Banks are the backbone for the economic development of country. The study talks about risk and returns of banks using its share price. When the returns are good it says that company is performing well and when risk is more with less returns then indicates towards banks poor performance. Even the study has emphasized that the banking sector is better sector for the investor to use them source in this sector.

This study is made on considering past six years data and it is seen in the study that private sector banks are performing better than public sector banks during the study period for the selected banks. Private sectors banks are posing threatening rivalry to public sector banks. Private sector banks are providing good rate of interests for depositors and also proposing various customer services to attract them and as a competition for public sector banks. Banks should concentrate on achieving profitability goals and focus on reducing risk and to increase business worldwide. Study will help banks to concentrate on its banking activities and performance. Public banks should concentrate on improving its performance and attracting more customers against private sector banks. The above table and graph which show the risk-return and movement of the bank's stock, we can observe that the 
bank of BARODA has the highest return from the other public banks, and HDFC bank has the highest return from the other privet banks. Even HDFC bank and YES bank shown highest return from all the banks as $20.755 \%$ and $17.528 \%$ respectively.

The risk of the sector, which represent by the covariance of the bank's stock shows HDFC and BANK OF BARODA as lowest risk in the sector of the study respectively. Beta measure consider as market risk which shown all the banks higher than beta, except HDFC Bank was found to be defensive stock with lower beta value as compared to the sector performance. The variation of beta signifies the variation of stock as compared to the market and it results in a lower beta value meaning the stock varies lower than the market.

\section{REFERENCE}

1. Kothari, C. R. (2004), "Research Methodology Methods and Techniques" "New Age International" New Delhi, India.
2. Chhaochharia S. (2008),"Capital Market Development"The Race between China and India, http://ssrn.com/abstract 1130074, pp. 1-15

3. JuhiAhuja (2012),"Indian Capital Market" An overview with Its Growth" VSRD International Journal of Business \& Management Research vol. 2(7), pp. 386-399.

4. Setiawanet.al, (2013) "Syariah and Conventional Stocks Performance of Public Companies Listed on Indonesia Stock Exchange " Journal of Accounting, Finance and Economics Vol. 3. No. 1. July 2013. Pp. $51-64$.

5. AnsarMahmood et.al, (2014)."A risk-return based model to measure the performance of portfolio management" Management Science Letters, 4.

6. Roger G. Ibbotson* and Daniel Y.-J. Kim ,(2015),"Risk and Return Within Stock Market" us university .

7. www.Bse India.Com

8. www.Moneycontrol.Com

9. www.Wikipedia.Com 